\title{
Control of the Construction Cost of a Residential District in Zhengzhou
}

\author{
Chaogai Xue, Jinku Zhou, Lili Qian, Maling Zhou \\ Institute of Mangement Engineering, Zhengzhou University, No. 100 Science Street, Zhengzhou, China \\ 1005426579@qq.com,2435602170@qq.com,923088622@qq.com
}

Keywords: Residential Area, Construction Cost Structure, Cost Control

\begin{abstract}
The real estate industry developed slowly from the 1980s and 1990s, and experienced a golden age as well as the development trough. Now it has gradually been mature in China. But there are still weak items in the scientific and reasonable cost control for China's real estate industry. In order to reduce the unnecessary development cost and maximize the profits of enterprises, real estate construction enterprises shall pursue quality and duration, and strengthen the cost of construction project control. Reducing the cost of real estate construction requires scientific control and effective management. This paper studies the residential district in Zhengzhou and analyzes of the construction cost of a residential district of Zhengzhou constitution as well as problems in detail to make recommendations for the construction project cost control.
\end{abstract}

\section{Introduction}

Over the past 30 years, China's market economy and the market system have gradually been improved, the city coverage is also getting higher and higher (Huiyuan Fan,2015). China's real estate industry has experienced more than 20 years of development of the golden period and has been initially formed in the national economic development position, and it has made an important contribution to China's economy. The real estate industry has become the main carrier of the national economy, and it not only promotes China's industrialization, modernization, urbanization process, but also promotes the reform of urban housing system, and gradually establishes a real estate market system (Chengbiao Han, 2015). While China is going to enter a comprehensive welloff society of the period, and people generally will raise the level of consumption and spiritual realm. So, people on the development of residential quarters are also increasingly demanded. Residential market is the important part of the real estate market, especially the development of residential quarters for the real estate industry to bring vitality will promote the sustainable development of real estate (Zhenya Tian,2015).

However, the development of China's real estate industry is still relatively short and the development concept of real estate project is still relatively backward. The actual cost of construction cost is not too high and has not yet formed a sound market system. So, it requires people in the future Cost control through the regular collection of construction cost data, timely summary, and find out the actual implementation of the process and the design of the deviation to correct them. People should learn to effectively control the construction cost of real estate projects by using scientific management. This paper introduces the construction cost of Zhengzhou residential area to study that how to strengthen the cost control of construction projects, reduce development cost, maximize the profits of construction enterprises and improve people's quality of life.

\section{The construction project cost control composition}

\subsection{Construction project development of the four stages}

Real estate development is divided into four stages, such as investment decision-making stage, preparation stage, construction stage and transaction stage. Firstly, these are the prerequisite for investing decision-making stage generally through research to obtain a lot of information, analyzing of market conditions and studying the feasibility construction projects in the smooth progress. 
Secondly, it is the preparatory stage, this stage is mainly faced with land, capital and projects plan and design of the problem, the overall plan of the construction project; Moreover, it is the construction stage, this stage is planned to be transformed into practical activities, and needs to coordinate human, material and financial resources in space. Finally, this stage is the process of converting the previous inputs into outputs and providing protection for the profits of the construction projects(Ying Lu,2013).

\subsection{The composition of the cost of construction projects}

The composition of the cost of real estate construction generally includes land cost, preliminary project cost, construction cost, supporting facilities, development period, taxes, unforeseen fees, management fees, sales cost and so on.

The cost of land mainly includes land cost, urban construction supporting fee, resettlement compensation fee. The preliminary project fee mainly includes the research, design and evaluation of the construction project in the early stage of the construction project (Linglong Zhou, 2012). Construction and installation cost are mainly included by the direct fee, the measure fee, the profit and the tax. The supporting facilities fee mainly consists of water supply, power supply, sewage, gas project fee and other sporadic project fee. The development period tax mainly consists of the tax payable during the construction period and the relevant government department. But the preparation of the project may lead to the more cost of construction mainly due to external environment, man-made, natural disasters and other uncertain factors during the construction period, the management cost includes management staff wages, welfare fees and so on (Jingwei Ding,2017). The sales cost mainly refers to marketing advertising planning cost, labor cost and other cost.

\section{The problems in the residential area construction project cost control}

\subsection{Investment decision-making stage}

Investmenting decision-making is a prerequisite for the development of district construction projects, it is necessary to do a good job in market research and to develop a reasonable price mechanism, the main problems are that the decision-making positioning is not accurate, and health care is not accurate at this stage. If these problems cannot be resolved and will have direct impact on the construction of the next step (Shaoguang Li, 2010).

\subsection{Preparation stage}

The preparatory stage is an important stage of the construction project of the district, which is directly related to the success of the construction of the district. This stage has mainly the problems of land, capital and project bidding and contract construction issues. During this period, there may be some problems, such as the illegal use of land rights, the financing difficulties of funds and the lack of contract terms in the bidding process, the unbalanced quotation of the tender and so on. The construction cost incurred mainly in the phase of the phase include land cost, pre-project cost, and the cost of land occupies an important part of the total cost.

\subsection{Construction stage}

Construction stage mainly takes the construction project into the practical, the main problems are that the design change management is not standardized, construction project material plan and the actual are not different and other issues in this process. The main cost includes construction and installation cost. Most of the cost would occurr such as Facilities fees, development period of taxes and fees, unforeseen fees, management fees, the total cost of construction projects accounted during the construction period, so it should focus on the construction phase.

\section{A district construction project cost control analysis in Zhengzhou}

\subsection{A residential area of the project overview in Zhengzhou}

A residential area is located in Jin Shui District, Zhengzhou City. It is completed in three phases, and the construction land area totaled 145473 square meters. A construction land area is 72737 square meters. Two construction land area is 58189 square meters. Three construction land area is 
14547 square meters. And the construction area is 141388 square meters, residential area is 95820 square meters, green area is 50750 square meters, floor area ratio is 1.76 , and green rate is $34 \%$.

\subsection{Analyzing the residential district construction cost structure}

The cost structure of the residential district is divided into eight categories, such as the cost of land, pre-construction, construction cost, public facilities construction cost, development period tax, project unforeseen expenses, management fees and sales cost. Details of its cost summary table see the table 1.

Table 1 Residential district cost structure

\begin{tabular}{|c|c|c|c|}
\hline $\begin{array}{l}\text { Serial } \\
\text { number }\end{array}$ & project name & Total (million) & Cost ratio \\
\hline 1 & Land cost & 16394 & $39.5 \%$ \\
\hline 2 & Preliminary works & 612 & $1.5 \%$ \\
\hline 3 & $\begin{array}{c}\text { Construction and installation } \\
\text { cost }\end{array}$ & 12237 & $29.5 \%$ \\
\hline 4 & Facilities fee & 3859 & $9.3 \%$ \\
\hline 5 & Tax during development period & 4615 & $11.1 \%$ \\
\hline 6 & Unforeseen expenses & 501 & $1.2 \%$ \\
\hline 7 & Management cost & 334 & $0.8 \%$ \\
\hline 8 & sales expense & 2699 & $6.5 \%$ \\
\hline 9 & other fee & 237 & $0.6 \%$ \\
\hline
\end{tabular}

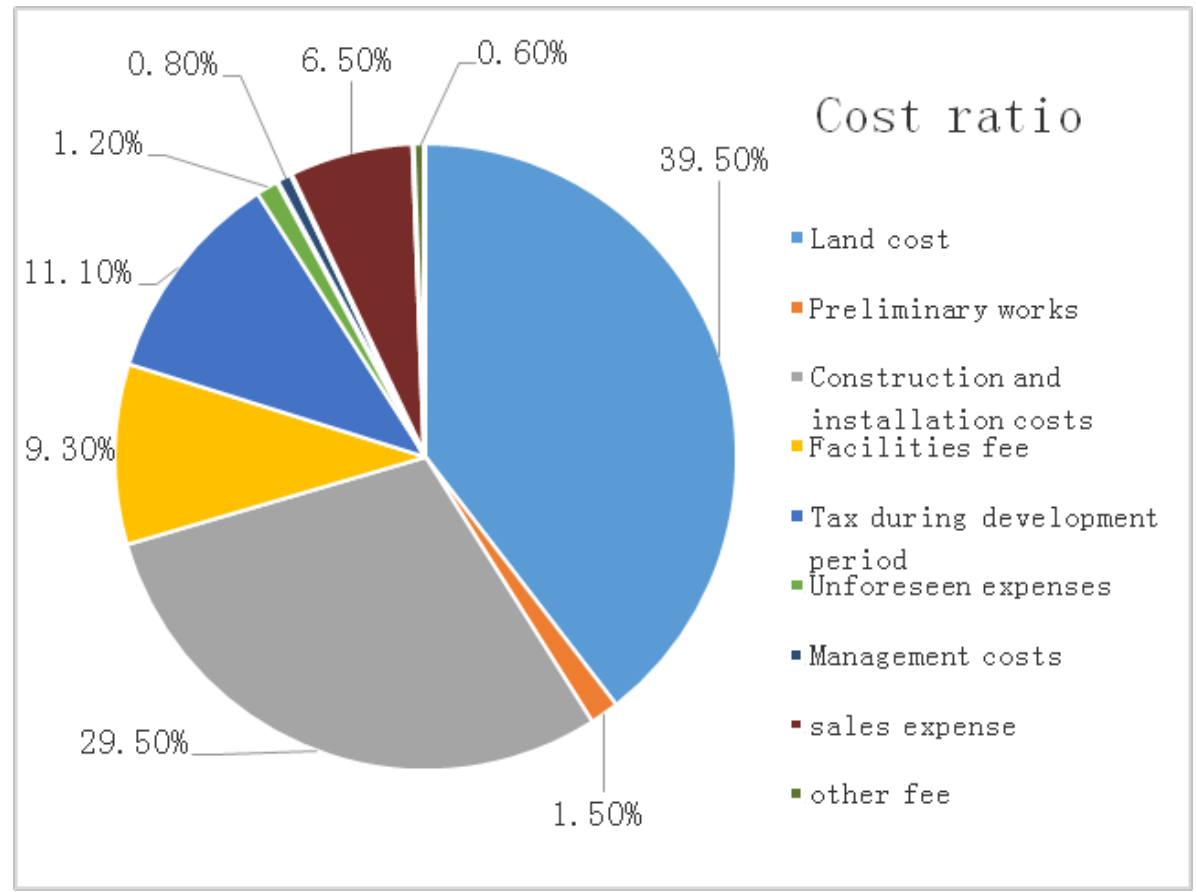

Fig.1 The proportion of the cost of a district in Zhengzhou

\subsection{Analyzing residential district cost control}

\subsubsection{Residential district early stage of the development of cost control}

The cost of the pre-development phase of the residential area mainly includes the land cost and the preliminary project cost. The land cost mainly includes the land acquisition tax, the demolition displacement fee, the land surveying and construction fee, the land tax and so on (Xiaoxia Liu, 2015). The land cost of the residential area is 163.94 million RMB and takes the total cost of 39.5\%(Fig.1). The more economically developed cities, the proportion of land is more higer in construction cost.

China's rapid economic development is inseparable from the outstanding contribution of the real estate industry, and the development of real estate cannot do without the strong support of the state 
and the government. At present, the land tax in the rapid development of China's urbanization period has become an important source of many government revenue, land operation has become the main tool for urban development, which requires the state and the government to rational planning and design of land.

The pre-project cost of the residential area mainly includes planning fee, design fee, feasibility study fee and so on. The preliminary cost of the district is only $1.5 \%$ of the total cost, Although the proportion of cost is not high, it plays a vital role in controlling the entire project.

\subsubsection{Cost control of residential district construction stage}

Construction and installation cost accounts for $29.5 \%$ of the total cost of construction, it is one of the important cost in the construction cost structure and occupies a heavy share. For developers, the cost control of a key point is to understand the content of the construction and installation, and should pay attention to the construction of the two sides to fulfill the contract in construction stage, analyze the construction and installation works, reasonable cost control, cost reduction expenses to improve its economic efficiency.

\subsubsection{Residential district facilities and the cost of tax control}

Supporting facilities and taxes and fees are also the important parts of the construction stage of the construction cost. Supporting facilities cost mainly includes water supply project cost, power supply project cost, landscaping project cost, community road square project cost, sewage engineering cost, gas engineering cost and other sporadic project cost. It directly affects the spending of residential quarters, It is showed that the construction of supporting facilities accounts for the construction of the total cost of 9.3\% from table 3-1.

It indicates that the district pays more attention to community service quality problems. During the development period, the taxes and fees mainly include business tax, urban construction maintenance tax, education surcharge, land value-added fee and residential supporting construction fee. These account for $11.1 \%$ of the total construction cost. This is consistent with the support of the state, the price level of the market and the people's level of living inseparable. For the government, it should be more on the construction enterprises in the tax to do more concession to encourage them to develop residential quarters, reduce their production cost, so that more low-income families can also buy inexpensive houses.

\section{The measures for the residential district construction cost control counter}

\subsection{Investment decision-making stage}

Investment decision-making stage must firstly do a good job of market research work. Next we can meet the different needs of people by market research information for timely processing and analysis, accurate project positioning.

\subsection{Preparation phase}

In the preparatory stage, the most important parts are the acquisition of land use rights and the rational use of national laws. While the developers should avoid blind competition and make reasonable decisions. It is necessary to examine the bidders, meet the qualifications of the tender to bid, but also a reasonable bid evaluation can reduce or avoid the possibility of unbalanced offer in the bidding and contract construction process. Next, we should strengthen the project negotiations, the tightness of the contract, and the construction side of the liability clause. The negotiations should be based on the equality of the two sides and on the basis of the contract for the negotiation of the contract. The construction unit should be in strict accordance with the requirements of the construction contract for the construction process.

\subsection{Construction and construction phase}

Firstly, it will occur with the design that does not match the situation and is affected by the external environment. When these circumstances happened, we should correctly deal with design changes in the project construction process, and master the design changes. Second, we should strengthen the supervision and management of on-site projects, reduce the quality of noncompliance and the requirements that is caused by the construction phase of the increase in cost. Furthermore, we should strengthen the claims management work and do a good counter-claim job 
to reduce the risk for the construction side and the construction side.

In addition, we must pay attention to the key point of the construction project cost control work to find the key point of cost control of residential quarters. The composition of residential quarter is a comprehensive system and contains more content, there are complex, uncertain and security issues. It requires us to carry out accurate inspection, careful plan, scientific decision-making to strengthen cost control and reduce unnecessary cost in the construction process.

We can find that the land cost in this district occupies $39.5 \%$ of the total cost, and is the most important part of the cost expenditure through the analysis of the construction cost structure of a residential district in Zhengzhou. The land cost is an important key point of cost control and requires developers to carry out construction projects.

Secondly, the district account for $29.5 \%$ of the total cost in the construction tooling project. This is another key point of cost control. For developers, the construction process should be in strict accordance with the construction design drawings for construction, control of construction and installation cost.

\section{Conclusions}

In the current competitive environment of the real estate market, on the one hand, strengthening the management of cost control is not only the basis of enterprise cost development strategy. It is also a major booster in the era of cost competition in order to benefit from the lowest cost to obtain greater of the profits and makes full use of resources. On the other hand, for real estate developers, it is on their own survival and development requirements and the developer's social responsibility for taking effective cost control of the management measures to control the cost of construction projects. Only in this way, we can promote the transformation of potential demand and activate the real estate market.

In addition, we should pay attention to the improvement of the overall quality of the site construction staff through the continuous training of education, promoting and strengthening their professional skills to enhance their pay levels and work performance level linked to improve their work enthusiasm.

\section{References}

[1] Huiyuan Fan. Construction cost control measures analysis [J]. Building materials decoration, 2015 (12).

[2] Chengbiao Han. Industrial building life cycle cost analysis [J]. Jiangsu Architecture, 2015 (6).

[3] Zhenya Tian. Analysis of high-rise residential district construction cost control [J]. Architectural knowledge .2015 (12).

[4] Linglong Zhou. Based on the life cycle of the industrialization of residential cost analysis [D]. Chongqing: Chongqing University, 2012.

[5] Jingwei Ding. Construction project construction cost control research [J]. Urban construction theory research (electronic version) 2017 (11).

[6] Shaoguang Li. Beijing residents of residential construction project cost control research [J]. Shopping modernization .2010 (24).

[7] Xiaoxia Liu. Four seasons Haitian residential district construction project cost control research [D]. China Ocean University 2015.

[8] Ying Lu. A commercial residential district two construction project cost management research [D]. Qingdao: China Ocean University, 2013. 